\title{
An Assessment of Genetic Relatedness between Soybean [Glycine max (L.) Merrill] Cultivars Using SSR Markers
}

\author{
Jayeeta Ghosh1, P. D. Ghosh' ${ }^{*}$, P. R. Choudhury ${ }^{2}$ \\ ${ }^{1}$ Department of Botany, University of Kalyani, Kalyani, India \\ ${ }^{2}$ Indian Council of Agricultural Research (ICAR), New Delhi, India \\ Email: ${ }^{*}$ pdgbot@yahoo.co.in
}

Received 4 July 2014; revised 23 August 2014; accepted 23 September 2014

Copyright (C) 2014 by authors and Scientific Research Publishing Inc.

This work is licensed under the Creative Commons Attribution International License (CC BY). http://creativecommons.org/licenses/by/4.0/

(c) (i) Open Access

In this present investigation, simple sequence repeat (SSR) analysis was used to determine the genetic relatedness among 32 soybean (Glycine max (L.) Merr.) cultivars from NRC for soybean, Madhya Pradesh. Among them 10 primer pairs showed 100\% amplification. Mainly three primer pairs could amplify polymorphic SSRs from all of these cultivars. The polymorphic information content (PIC) among cultivars varied from 0.21 (S26) to 0.83 (S27) with an average of 0.51 . Pairwise coefficients of genetic similarity between all genotypes ranged from 0.76 to 1.00. Unweighted pair-group method arithmetic average (UPGMA) analysis allocated the cultivars in 2 major clusters or groups and 6 sub-clusters. Of the two major clusters one contained 20 cultivars and the other contained 12 cultivars. The largest cluster was again divided into three sub-clusters I, II and III with 12, 2 and 6 cultivars respectively and the smallest cluster was divided into three sub-clusters IV, V, VI containing 7, 4 and 2 cultivars respectively. These results suggest that SSR markers are efficient for measuring genetic relatedness among soybeans irrespective of a wide agro-climatic zone. Genetic relationship assessments among soybean cultivars in India could provide useful information for efficient utilization of these materials, especially for widening the genetic base.

\section{Keywords}

SSR, UPGMA, Similarity Coefficient, PIC, Genetic Base

\section{Introduction}

Taxonomically, soybean belongs to the order Fabales, the family Fabaceae, the subfamily Faboidae and the genus glycine. The genus glycine is divided into two subgenera, glycine including 16 perennial species and Soja

"Corresponding author.

How to cite this paper: Ghosh, J., Ghosh, P.D. and Choudhury, P.R. (2014) An Assessment of Genetic Relatedness between Soybean [Glycine max (L.) Merrill] Cultivars Using SSR Markers. American Journal of Plant Sciences, 5, 3089-3096. 
(Moench) F.J. Herm having two annual species, Glycine soja Siebold and Zucc $(2 \mathrm{n}=40)$ and G. $\max (\mathrm{L}$.) Merrill $(2 \mathrm{n}=40)$ [1]. This crop is aptly called as "Golden Bean" or "Miracle Crop" of the 20th century, because of its multiple uses. Apart from quality protein and oil, soybean also has many therapeutic components viz., lactose free fatty acids, antioxidants like vitamins $\mathrm{C}, \mathrm{K}$, and D and folic acid, vitamins of B complex group viz., nicotinic acid $(23 \mu \mathrm{g} / \mathrm{g})$, pantothenic acid $(15 \mu \mathrm{g} / \mathrm{g})$, thiamine $(12 \mu \mathrm{g} / \mathrm{g})$, pyridoxine $(8 \mu \mathrm{g} / \mathrm{g})$, riboflavin $(3.5 \mu \mathrm{g} / \mathrm{g})$ and biotin $(0.7 \mu \mathrm{g} / \mathrm{g})$ and isoflavones like genistein and daidzein [2]. Besides fixing the atmospheric nitrogen, this crop has the ability to grow in a range of environments, to reduce soil erosion, to suppress weeds and to suit inter as well as sequential cropping pattern.

With low input demand, this pearl of orient fetched high market price [3]. Yet, the crop is not cultivated over an area it deserves in India especially in the eastern states. This versatile natured crop and the wide yield gap, call for concerted pre-breeding efforts to widen the genetic base suitable to specific agro-climatic conditions.

Genetic diversity is normally assessed by common morphological traits. However, such traits are affected by environmental effects, developmental stages of the plant, and also the type of plant materials. Several replications require establishing the genotypic contributions. Hence, there is a need to go in for a highly reliable and precise method for assessment of genetic variability with no environmental effects. Most diversity studies on cultivated soybean published by now have focused on North American [4]-[6], Asian [7]-[12] as well as South American [13] soybean germplasms. Different PIC values were obtained using different genetic materials of soybean and have been reported by SSR marker studies [8] [14]. Likewise Indian cultivars are checked with high throughput markers like SSRs and SNPs to re-establish its varietal correlations.

Molecular markers have brought phenomenal changes in the area of plant biotechnology by their ability to produce unique DNA profiles in various crops. Simple sequence repeat markers (SSR) are being extensively used in genome studies, marker-assisted selection, and cultivar identification. These are also well-known for their versatility in providing a quick assay and for their highly informative data [15]-[17]. In India several groups are working on soybean varital studies. Ten soybean varieties were evaluated for seven seed traits. Seed coat color, hilum color, seed shape and seed size were stable traits and could be used for development of a varietal identification key [18]. The genetic diversity of the soybean genotypes of north-east region of India has been reported [19]. Soybean diversity pattern may serve as a valuable guide for finding and incorporating new lines into elite soybean genotypes [20]. The objective of this study was 1) to test the relationship among the 32 cultivars of India by SSR analysis, 2) to generate molecular fingerprints of cultivars currently used commercially in India and cluster them into groups according to genetic similarity by using marker analysis techniques. This information should be useful for soybean breeding programs and genetic studies.

\section{Materials and Methods}

The material used in this study comprised of 32 cultivars of soybean which includes most of the released varieties in India and belongs to different agro climatic zones provided in Table 1. The detailed information regarding experimental material along with their pedigree used in the study is given in the Table 2. The experiment was conducted during the period of 2010-2012 at Department of Plant Molecular Biology and Biotechnology, DSR, Mau and Department of Botany, University of Kalyani, West Bengal.

\subsection{DNA Extraction}

Leaf samples were collected from 30 days old plants of soybean varieties (as listed in Table 2) raised at Department of Molecular Biology, Directorate of Seed Research (DSR) Mau, Uttar Pradesh. 5 - 8 terminal leaves from each cultivars were collected in an ice box and the collected leaf samples were used to extract DNA following the CTAB [21] method. Isolated DNA was quantified using spectrophotometer (Cecil, Germany). $998 \mu 1$ of TE buffer was taken in a quartz cuvette and $2 \mu \mathrm{l}$ of extracted genomic DNA was added to it. The optical density (absorbance A) was taken at $260 \mathrm{~nm}$ (A260) and $280 \mathrm{~nm}$ (A280). The amount of the DNA present in the solution was calculated from absorption at $260 \mathrm{~nm}$ (A260) and the purity of DNA was calculated by A260/A280 ratio. For an ideal DNA preparation the A260/A280 ratio should be $\geq 1.8$. Formula for calculating the DNA concentration:

DNA concentration $=$ spectral reading $($ A260 $) \times 50 \mu \mathrm{g} / \mathrm{ml} \times$ dilution factor for double stranded genomic DNA, 1 O.D. corresponds to $50 \mu \mathrm{g} / \mathrm{ml}$ of DNA [22]. 
Table 1. Soybean agro-climatic zone in India.

\begin{tabular}{|c|c|c|}
\hline Agro-Climatic Zone & States Covered under the Zone & Varieties \\
\hline North Hill Zone & HP, Uttaranchal & $\begin{array}{c}\text { Bragg, Palam Soya, Shivaleek, Lee, Punjab 1, } \\
\text { Pusa 20, VL Soya }\end{array}$ \\
\hline North Plain Zone & $\begin{array}{l}\text { Punjab, Haryana, Delhi, NE Plains of UP, } \\
\text { Western Bihar }\end{array}$ & $\begin{array}{l}\text { Bragg, PK416, Shilajeet PS1024, } \\
\text { Ankur, Punjab 1, Alankar }\end{array}$ \\
\hline Central Zone & $\begin{array}{l}\text { MP, Bundelkhand Region of UP, Rajasthan, } \\
\text { Gujarat, Western Parts of Maharashtra }\end{array}$ & $\begin{array}{l}\text { JS95-60, Ahilya 1, Durga, Gaurav, Gujarat 202, } \\
\text { Kalitur, Type-49, Punjab 1, Bragg, NRC7, DS228 }\end{array}$ \\
\hline Southern Zone & $\begin{array}{l}\text { Karnataka, TN, AP, Kerala, } \\
\text { Southern Parts of Maharashtra }\end{array}$ & $\begin{array}{l}\text { TAMS98-21, Bragg, Monetta, Hardee, } \\
\text { Improved Pelican, ADT 1, Sneha, Co Soya } 2\end{array}$ \\
\hline North Eastern Zone & $\begin{array}{l}\text { Assam, West Bengal, Meghalaya, } \\
\text { Eastern Bihar, Orissa, Chhattisgarh }\end{array}$ & Bragg, Birsa Soya \\
\hline
\end{tabular}

Table 2. List of experimental materials.

\begin{tabular}{|c|c|c|}
\hline Sl No. & Name of Variety & Pedigree \\
\hline 1. & Gujarat 202 & - \\
\hline 2. & Pusa 20 & Bragg $\times$ Lee \\
\hline 3. & IP & Tanloxi $\times$ P.I60406 \\
\hline 4. & PK 416 & UPSM 534 × PK-317 \\
\hline 5. & Shilajeet & Selection from EC 9309 \\
\hline 6. & Lee & $\mathrm{S} 100 \times \mathrm{CNS}$ \\
\hline 7. & Punjab 1 & Selection from Nanking Variety \\
\hline 8. & Ankur & SPS from Composite of 22 Crosses \\
\hline 9. & TAMS 98-21 & Mutant of JS 80-21 \\
\hline 10. & Hara Soya & $($ Ankur $\times$ Himso 330 $) \times$ Bragg \\
\hline 11. & Ahilya 1 & Induced Mutant of Bragg \\
\hline 12. & Kalitur & Land Race \\
\hline 13. & JS-71-05 & Selection for Lee Type Exotic Material \\
\hline 14. & Type 49 & Selection from Indigenous Material \\
\hline 15. & PS 1024 & PK-308 × PK-317 \\
\hline 16. & Co Soya 2 & UGM-21 × JS-335 \\
\hline 17. & Hardee & D49-772 × IP \\
\hline 18. & Monetta & An Exotic Variety EC-2587 \\
\hline 19. & Gaurav & EC-11437 × Bragg \\
\hline 20. & Vl Soya 1 & Mutant of Bragg \\
\hline 21. & ADT-1 & Selection from Hill Variety \\
\hline 22. & Durga & Selection from EC 172576 \\
\hline 23. & Palam Soya & Land Race \\
\hline 24. & DS-228 & JS $335 \times$ DS181 (PI 4623133) \\
\hline 25. & JS-95-60 & Selection from PS 73-22 \\
\hline 26. & Alankar & D63-6049 × D61-4249 \\
\hline 27. & Raus-5 & - \\
\hline 28. & Birsa Soya 1 & - \\
\hline 29. & Sneha & Hardee $\times$ Monetta \\
\hline 30. & Bragg & Jackson × D49 \\
\hline 31. & NRC 7 & Selection from S69-96 \\
\hline 32. & Shivaleek & Selection from PK 7355 \\
\hline
\end{tabular}




$$
\text { Dilution Factor }=\frac{998 \mu \mathrm{l} \mathrm{TE} \text { buffer }+2 \mu \mathrm{l} \text { DNA }}{2 \mu \mathrm{l}}
$$

DNA was run on 0.8 percent agarose gel stained with ethidium bromide following a standard method [23] and was visualized in a translluminator and photographed using Gel Doc (BioRad).

\subsection{Polymerase Chain Reaction}

The PCR (Polymerase Chain Reactions) were carried out in $25 \mu$ l volume with the reaction mixture. The quantified DNA diluted and prepared master mix with $10 \times$ taq buffer $(2.5 \mu \mathrm{L})$, Taq DNA pol $(.2 \mu \mathrm{L})$, Forward and Reverse primer $(1 \mu \mathrm{L})$, dNTPs $(25 \mu \mathrm{L})$ PCR was performed at an initial denaturation temperature of $94^{\circ} \mathrm{C}$ for 4 min followed by 35 cycles of 1 min denaturation at $94^{\circ} \mathrm{C}, 1$ min annealing at a temperature $47^{\circ} \mathrm{C}-55^{\circ} \mathrm{C}$ lower than melting point for each primer (Table 3) and 2 min extension at $72^{\circ} \mathrm{C}$ with a final extension of $72^{\circ} \mathrm{C}$ for 7 min using a thermal cycle (Perkin Elmer gene Amp 2400 PCR system). PCR products were run on 3\% MetaPhor ${ }^{\mathrm{R}}$ agarose gel (Lonza) [24] [25] with 1\% TBE buffer. DNA was visualized via ethidium bromide added to the gels.

\subsection{Data Analysis}

Amplified fragments were scored as binary data, i.e. presence as 1 and absence as 0 , for the homologous bands. Diffused bands or bands revealing ambiguity in scoring treated as missing data. Genotypes showing two allelic bands with equal intensity considered as heterozygous for the locus. The polymorphic information content (PIC) values for each primer were calculated using the following formula PIC $=1-\sum \mathrm{Pij}^{2}$ Where $\mathrm{Pi}$ is the relative frequency of $j^{\text {th }}$ allele for $i^{\text {th }}$ marker, and summed over $n$ number alleles [26]. Genetic relationships among individuals were quantified by the Jaccard's coefficient [27]. It was used to calculate similarity between pairs of accessions, where, $\left[J=n_{x, y}\left(n_{t}-n_{z}\right)\right], n_{x, y}$ is the number of bands common to sample A and sample $B ; n_{t}$ the total number of bands present in all samples and $\mathrm{n}_{\mathrm{z}}$ the total number of bands not present in $\mathrm{A}$ and $\mathrm{B}$ but found in other samples. Based on the similarity matrix obtained from Jaccard's coefficient, sequential agglomerative hierarchical non-overlapping (SAHN) clustering was done using unweighted pair group method with arithmetic averages (UPGMA) and a principal coordinate (PCA) analysis according to the extracted Eigen vectors using NTSYS-pc software version 2.2 Statistical package [26].

\section{Result}

Total 15 SSR primers screened and among them 10 SSR primers listed in Table 3 have shown $100 \%$ amplification of all 32 cultivars and 3 primers given clear polymorphism. 8 alleles of length between 50 bp to 150 bp were identified across 10 primer pairs. Total 45 polymorphic bands have been detected across 32 cultivars. PIC a measure of the allelic diversity calculated for primer S26, S27 and S43 are 0.26, 0.83 and 0.46 and hence were the most informative for distinguishing among the soybean genotypes. In Figure 1(A) Primer S27 and in Figure 1(B) Primer S43 showing the 32 cultivars up lane 1 - 16 (soy1 to soy-16) and down lane 1 - 16 (soy17 to soy32) and M denotes the marker i.e. Low range Gene Ruler ${ }^{\mathrm{TM}}$ DNA ladder $\neq$ SM1191/2/3/bp ng/0.5. The dendrogram based on genetic similarities between cultivars showed that (Figure 2) there are two major clusters and 6 sub-clusters. Three sub clusters of the larger cluster named as I, II and III with 12, 2 and 6 cultivars and the smaller cluster again divided into three sub clusters named as IV, V, VI with 7, 4 and 2 cultivars. In sub cluster I the cultivars groups together are soy1-Gujarat 202, soy2-Pusa 20, soy-3-Improved Pelican, soy7-Punjab 1, soy8-Tams 98-21, soy10-Hara soya, soy12-Kalitur, soy18-Monetta, soy29-Sneha, soy30-Bragg, soy32-Shivaleek. This is the largest among six sub clusters. In sub cluster II only varieties are soy27-Raus 5, soy28-Birsa soya. Sub cluster III consist of soy21-ADT-1, soy22-Durga, soy23-Palam soya, soy25-JS-95-60, soy26-Alankar, soy31-NRC 7. The smaller cluster consist of 7 members i.e. soy4-PK 416, soy5-Shilajeet, soy6-Lee, soy8-Ankur, soy13-JS-71-05, soy15-PS-1024 and soy17-Hardee. $V^{\text {th }}$ sub cluster consist of soy14-Type-49, soy16-Co soya-2 soy20-VL Soya soy24-DS-228 and the last $\mathrm{VI}^{\text {th }}$ is the smallest having only one member soy19-Gaurav. Jaccard coefficient ranged between 0.76 to 1.00 . From the Scatter plot expressing genetic distances among the cultivars it is observed that cultivars are genetically very similar. The contribution of first two coordinates (F1:F2) is 93.96\%. Contribution of each coordinates (F3, F4) further was found less than $10 \%$. Therefore, the best fittest coordinates has been given to explain the total variation among 32 cultivars (Figure 3). 
Table 3. SSR primer details.

\begin{tabular}{|c|c|c|c|}
\hline Primer Code & Sequence (5'-3') & Length (bp) & $\mathrm{AT}\left({ }^{\circ} \mathrm{C}\right)$ \\
\hline S26 & $\begin{array}{l}\text { F-5'GCCAAGTCACACACACACCAAG3' } \\
\text { R-3'TTTGTTTGATCTATGCAATTGC5' }\end{array}$ & $\begin{array}{l}20 \\
22\end{array}$ & 55 \\
\hline S21 & $\begin{array}{l}\text { F-5'AAAAAAGGTTTCACTGGCACT3' } \\
\text { R-3'ATTTACGGATCTGCCATTCTC5' }\end{array}$ & $\begin{array}{l}21 \\
21\end{array}$ & 50 \\
\hline S22 & $\begin{array}{l}\text { F-5’TTTGGAAATGAGTGAAATGGA3' } \\
\text { R-3'GGATTAGATCAGGACACACATACA5' }\end{array}$ & $\begin{array}{l}24 \\
24\end{array}$ & 50 \\
\hline S23 & $\begin{array}{l}\text { F-5'AAGGAGGTAAAATGAAACAAACTT3' } \\
\text { R-3'TCCCTCCCAAGTTAAAATCAA5' }\end{array}$ & $\begin{array}{l}24 \\
21\end{array}$ & 47 \\
\hline S27 & $\begin{array}{l}\text { F-5'GATTTTTTGCCTTCCTTTCTG3', } \\
\text { R-3'TTGAACAGCAAGAGTTTGGAC5', }\end{array}$ & $\begin{array}{l}21 \\
21\end{array}$ & 50 \\
\hline S12 & $\begin{array}{l}\text { F-5'TTTGGACTCTTTTTAGGGTTAGG3’ } \\
\text { R-3’GGGCATTTAAGAAGTTGCTCT5' }\end{array}$ & $\begin{array}{l}23 \\
21\end{array}$ & 50 \\
\hline S43 & $\begin{array}{l}\text { F-5’CGTTTCATTCCCATGCCAATA3’' } \\
\text { R-3’CCCGCATCTTTTTCAACCAC5' }\end{array}$ & $\begin{array}{l}21 \\
20\end{array}$ & 52 \\
\hline S13 & $\begin{array}{l}\text { F-5’GCTCAGTTATTTGGTTCATATGC3' } \\
\text { R-3’TCACAATTAACTGCAAATTTCTTC5' }\end{array}$ & $\begin{array}{l}23 \\
24\end{array}$ & 50 \\
\hline S1 & $\begin{array}{c}\text { F-5'TTGCAAAATAGATTCCAATG3' } \\
\text { R-3'GACTCTCAGATTGATAATAATTTC5' }\end{array}$ & $\begin{array}{l}20 \\
21\end{array}$ & 46 \\
\hline S30 & $\begin{array}{l}\text { F-5'CAGGCTTTTTTCTTTTTCTTCTT3' } \\
\text { R-3’CCACACCACTGTCCCTTTGA5' }\end{array}$ & $\begin{array}{l}22 \\
20\end{array}$ & 50 \\
\hline
\end{tabular}
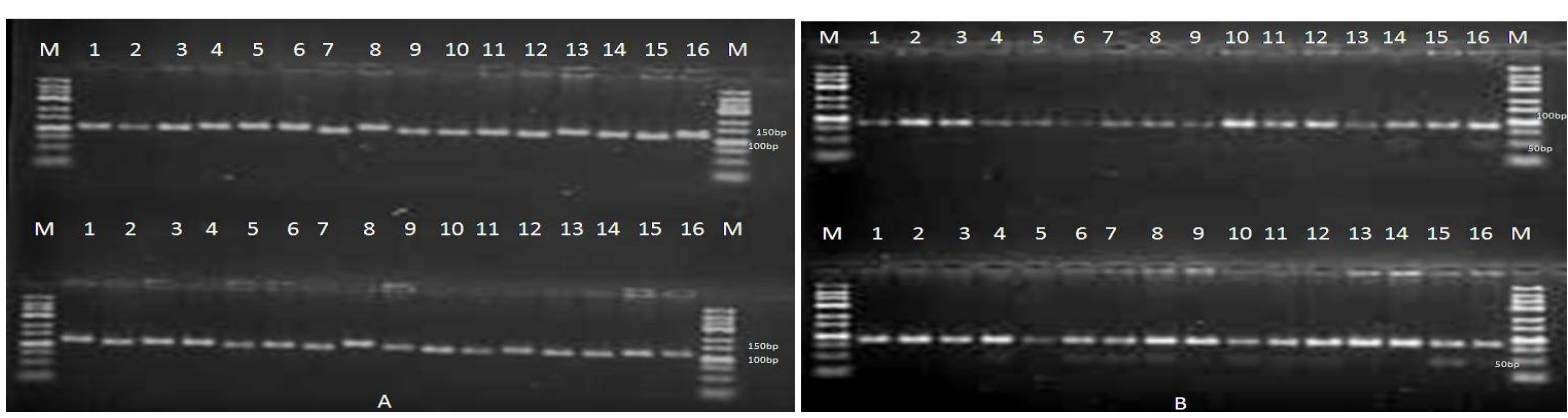

Figure 1. (A) Primer S27 and (B) Primer S43 showing 32 cultivars up lane 1 - 16 (soy1 to soy-16) and down lane 1 - 16 (soy17 to soy32) and M denotes the marker i.e. low range Gene Ruler ${ }^{\mathrm{TM}}$ DNA ladder $\neq$ SM1191/2/3/bp ng/0.5.

\section{Discussion}

In this present study the genetic closeness and low levels of genetic diversity were clearly established and similarity coefficient range (0.76 to 1.00) and scatter plot expressing genetic distances supported this fact. In Figure 3 the genetic distance proved to be very less i.e. maximum cultivars almost showing similar plot area on the scatter plot diagram. An early report had been established between the 15 certified soybean varieties under cultivation in Thailand. Pair wise coefficients of genetic similarity between all genotypes ranged from 0.73 to 1.00 , which is consistent with present study. Among them $64 \%$ were $\geq 0.87$ [28]. The analysis of allelic profiles at 20 SSR loci produced an average of 11.9 alleles and a mean genetic diversity of 0.782 in 131 soybean accessions introduced from 14 Asian countries [8]. This low level of genetic diversity and such a highest level of similarity may be ascribed to the emphasis on direct introductions, selection from introduced germplasm and single cross hybrids (some of which shared common parents) in the soybean breeding programs. Therefore, inclusion of more diverse germplasm in the soybean breeding programs may provide the genetic variability necessary to permit continued progress and broad adaptation. A previous report showed that higher genetic diversity could be found among exotic soybean introductions from different countries [29]. The genetic relationships among soybean genotypes may facilitate the selection of parents in breeding programs with the hypothesis that the more genetically diverse the parents, the more likely they are to possess unique alleles for traits of interest [5]. This study will help to restructure the Indian soybean cultivars to widen the genetic base to introduce new varieties. 


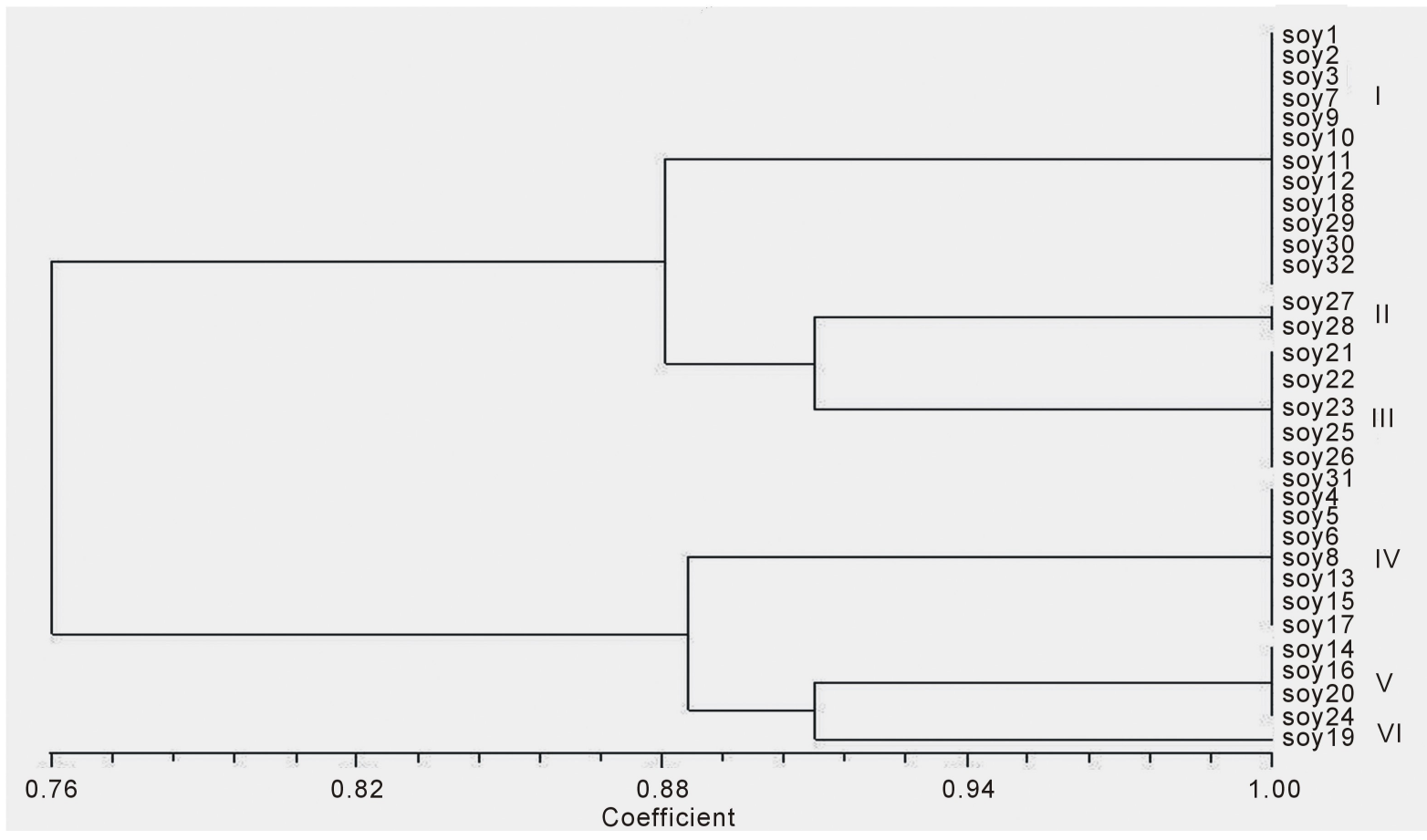

Figure 2. Dendrogram showing similarity coefficients and genetic relationships among 32 soybean cultivars.

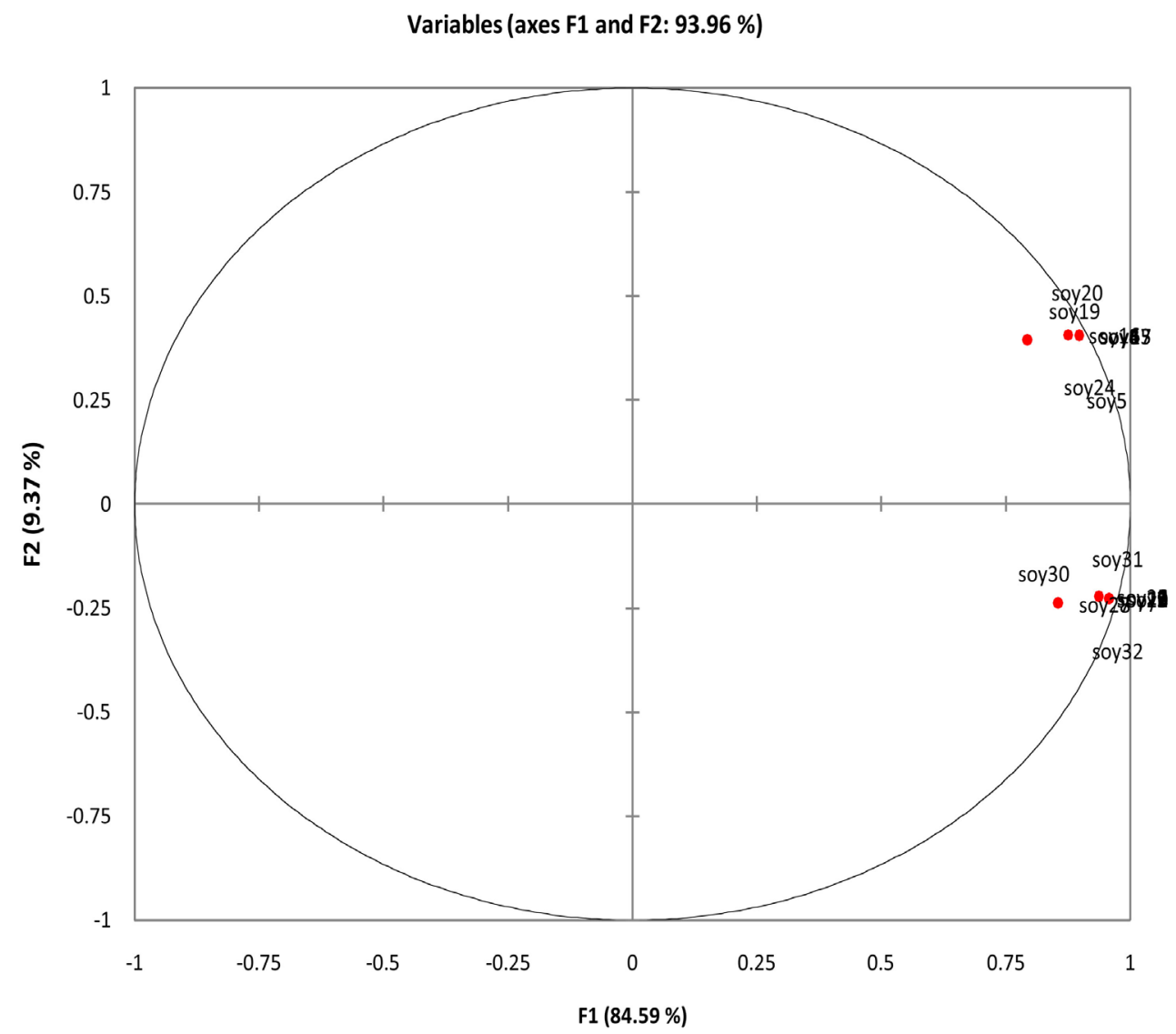

Figure 3. Scatter plot expressing genetic distances among the cultivars. 


\section{Acknowledgements}

The authors express their gratitude to Ex. Project Director Dr. Asit B. Mandal for providing the field and some early screening at Molecular Biology Lab in Directorate of Seed Research, Mau. They are also very appreciative to NRC Soybean, MP, for providing the seeds and helpful information. This research was supported by project grant from ICAR.

\section{References}

[1] Singh, R.J. and Hymowitz, T. (1999) Soybean Genetic Resources and Crop Improvement. Genome, 42, 605-616. http://dx.doi.org/10.1139/g99-039

[2] Mathur, S. (2004) Soybean the Wonder Legume. Beverage Food World, 31, 61-62.

[3] Gautam, P. and Pant, L.M. (2004) Soybean: A “Miracle Bean” for Uttaranchal. Indian Farmers Digest.

[4] Brown-Guedira, G.L., Thompson, J.A., Nelson, R.L. and Warburton, M.L. (2000) Evaluation of Genetic Diversity of Soybean Introductions and North American Ancestors Using RAPD and SSR Markers. Crop Science, 40, 815-823. http://dx.doi.org/10.2135/cropsci2000.403815x

[5] Narvel, J.M., Fehr, W.R., Chu, W.C., Grant, D. and Shoemaker, R.C. (2000) Simple Sequence Repeat Diversity among Soybean Plant Introductions and Elite Genotypes. Crop Science, 40, 1452-1458. http://dx.doi.org/10.2135/cropsci2000.4051452x

[6] Fu, Y.B., Peterson, G.W. and Morrison, M.J. (2007) Genetic Diversity of Canadian Soybean Cultivars and Exotic Germplasm Revealed by Simple Sequence Repeat Markers. Crop Science, 47, 1947-1954. http://dx.doi.org/10.2135/cropsci2006.12.0843

[7] Abe, J., Xu, D.H., Suzuki, Y., Kanazawa, A. and Shimamoto, Y. (2003) Soybean Germplasm Pools in Asia Revealed by Nuclear SSRs. Theoretical and Applied Genetics, 106, 445-453.

[8] Xie, H., Guan, R., Chang, R. and Qiu, L. (2005) Genetic Diversity of Chinese Summer Soybean Germplasm Revealed by SSR Markers. Chinese Science Bulletin, 50, 526-535. http://dx.doi.org/10.1007/BF02897476

[9] Wang, L., Guan, R., Liu, Z.X., Chang, R. and Qiu, L. (2006) Genetic Diversity of Chinese Cultivated Soybean Revealed by SSR Markers. Crop Science, 46, 1032-1038. http://dx.doi.org/10.2135/cropsci2005.0051

[10] Li, L., Wang, X., Gai, J. and Yu, D. (2008) Isolation and Characterization of a Seed-Specific Isoform of Microsomal Omega-6 Fatty Acid Desaturase Gene (FAD2-1B) from Soybean. DNA Sequence, 19, 28-36. http://dx.doi.org/10.1080/10425170701207208

[11] Wang, F., Zhao, T.J., Yu, D.Y., Chen, S.Y. and Gai, J.Y. (2008) Inheritance and QTL Analysis of Submergence Tolerance at Seedling Stage in Soybean [Glycine max (L.) Merr.]. Acta Agronomica Sinica, 34, 748-753. http://dx.doi.org/10.3724/SP.J.1006.2008.00748

[12] Yoon, M., Lee, J., Kim, C., Kang, J., Cho, E. and Baek, H. (2009) DNA Profiling and Genetic Diversity of Korean Soybean (Glycine max (L.). Merrill) Landraces by SSR Markers. Euphytica, 165, 69-77. http://dx.doi.org/10.1007/s10681-008-9757-7

[13] Bonato, A.L.V., Calvo E.S., Geraldi, I.O. and Arias, C.A.A. (2006) Genetic Similarity among Soybean (Glycine max (L). Merrill) Cultivars Released in Brazil Using AFLP Markers.

[14] Chotiyarnwong, O., Chatwachirawong, P., Chanprame, S. and Srinives, P. (2007) Evaluation of Genetic Diversity in Thai Indigenous and Recommended Soybean Varieties by SSR Markers. Thai Journal of Agricultural Science, 40, 119-126.

[15] Song, Q.J., Quigley, C.V., Nelson, R.L., Carter, T.E., Boerma, H.R., Strachan, J.L. and Cregan, P.B. (1999) A Selected Set of Trinucleotide Simple Sequence Repeat Markers for Soybean Cultivar Identification. Plant Varieties and Seeds, 12, 207-220.

[16] Cregan, P.B., Jarvik, T., Bush, A.L., Shoemaker, R.C., Lark, K.G., Kahler, A.L., Kaya, N., Van Toai, T.T., Lohnes, D. G., Chung, J. and Specht, J.E. (1999) An Integrated Genetic Linkage Map of the Soybean Genome. Crop Science, 39, 1464-1490. http://dx.doi.org/10.2135/cropsci1999.3951464x

[17] Cregan, P.B., Mudge, J., Fickus, E.W., Marek, L.F., Danesh, D., Denny, R., Shoemaker, R.C., Matthews, B.F., Jarvik, T. and Young, N.D. (1999) Targeted Isolation of Simple Sequence Repeat Markers through the Use of Bacterial Artificial Chromosomes. Theoretical and Applied Genetics, 98, 919-928. http://dx.doi.org/10.1007/s001220051151

[18] Ravikumar, M. and Narayanasamy, S. (1999) Identification of Soybean Varieties Based on Seed and Morphological Characters. Current Research, 28, 50-52.

[19] Borthakur, P.N. (1989) Exploiting Biological Diversity for Breeding Crop Plants for North-Easternregion. Proceedings of Indian National Science Academy, Biological Sciences, 55, 185-192. 
[20] Kisha, T.J., Dher, B.W., Hoyt, J.M. and Sneller, C.H. (1998) Genetic Diversity among Soybean Plant Introduction and North American Germplasm. Crop Science, 38, 1669-1680. http://dx.doi.org/10.2135/cropsci1998.0011183X003800060042x

[21] Murray, M.G. and Thompson, W.F. (1980) Rapid Isolation of High Molecular Weight Plant DNA. Nucleic Acids Research, 8, 4321-4325. http://dx.doi.org/10.1093/nar/8.19.4321

[22] Sambrook, J. and Russed, D.W. (2001) Molecular Cloning. A Laboratory Manual. 3rd Edition, Cold Spring Harbor Laboratory Press, New York.

[23] Sambrook, J., Frotsch, E.F. and Maniatis, T. (1989) Molecular Cloning. A Laboratory Manual. 2nd Edition, Cold Spring Harbor, New York.

[24] Rana, M.K., Archak, S. and Singh, R. (2012) An E-Manual on "Molecular Marker Techniques for Genotype Identification”. NBPGR, Pusa Campus, New Delhi.

[25] Asif, M., Mehboob-ur-Rahman, Mirza, I.J. and Yusuf, Z. (2008) High Resolution Metaphore Agarose Gel Electrophoresis for Genotyping with Microsatellite Markers. Pakistan Journal of Agricultural Sciences, 45, 75-79.

[26] Rohlf, F.J. (2000) NTSYS-pc: Numerical Taxonomy and Multivariate Analysis System, Version 2.2. Exeter Software. Setauket, New York.

[27] Jaccard, P. (1908) Nouvelles recherches sur la distribution florale. Bulletin de la Société Vaudoise des Sciences Naturelles, 44, 223-270.

[28] Tantasawat, P., Trongchuen, J., Prajongjai, T., Jenweerawat, S. and Chaowiset, W. (2011) SSR Analysis of Soybean (Glycine max (L.) Merr.) Genetic Relationship and Variety Identification in Thailand. American Journal of Cultural Sociology, 5, 283-290.

[29] Chowdhury, A.K., Srinives, P., Tongpamnak, P., Saksoong, P. and Chatwachirawong, P. (2002) Genetic Relationship among Exotic Soybean Introductions in Thailand: Consequence for Varietal Registration. Science Asia, 28, 227-239. http://dx.doi.org/10.2306/scienceasia1513-1874.2002.28.227

\section{Abbreviations}

SSR: Simple Sequence Repeats

UPGMA: Unweighted Pair Group Method with Arithmetic Mean

PIC: Polymorphic Information Content

CTAB: Cetyl Trimethylammonium Bromide

TBE: Tris/Borate/EDTA

SAHN: Sequential Agglomerative Hierarchical Non-Overlapping 
Scientific Research Publishing (SCIRP) is one of the largest Open Access journal publishers. It is currently publishing more than 200 open access, online, peer-reviewed journals covering a wide range of academic disciplines. SCIRP serves the worldwide academic communities and contributes to the progress and application of science with its publication.

Other selected journals from SCIRP are listed as below. Submit your manuscript to us via either submit@scirp.org or Online Submission Portal.
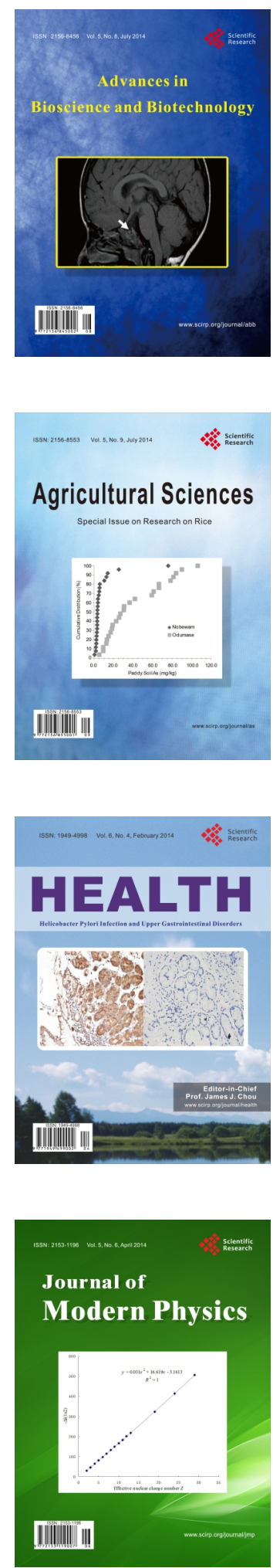
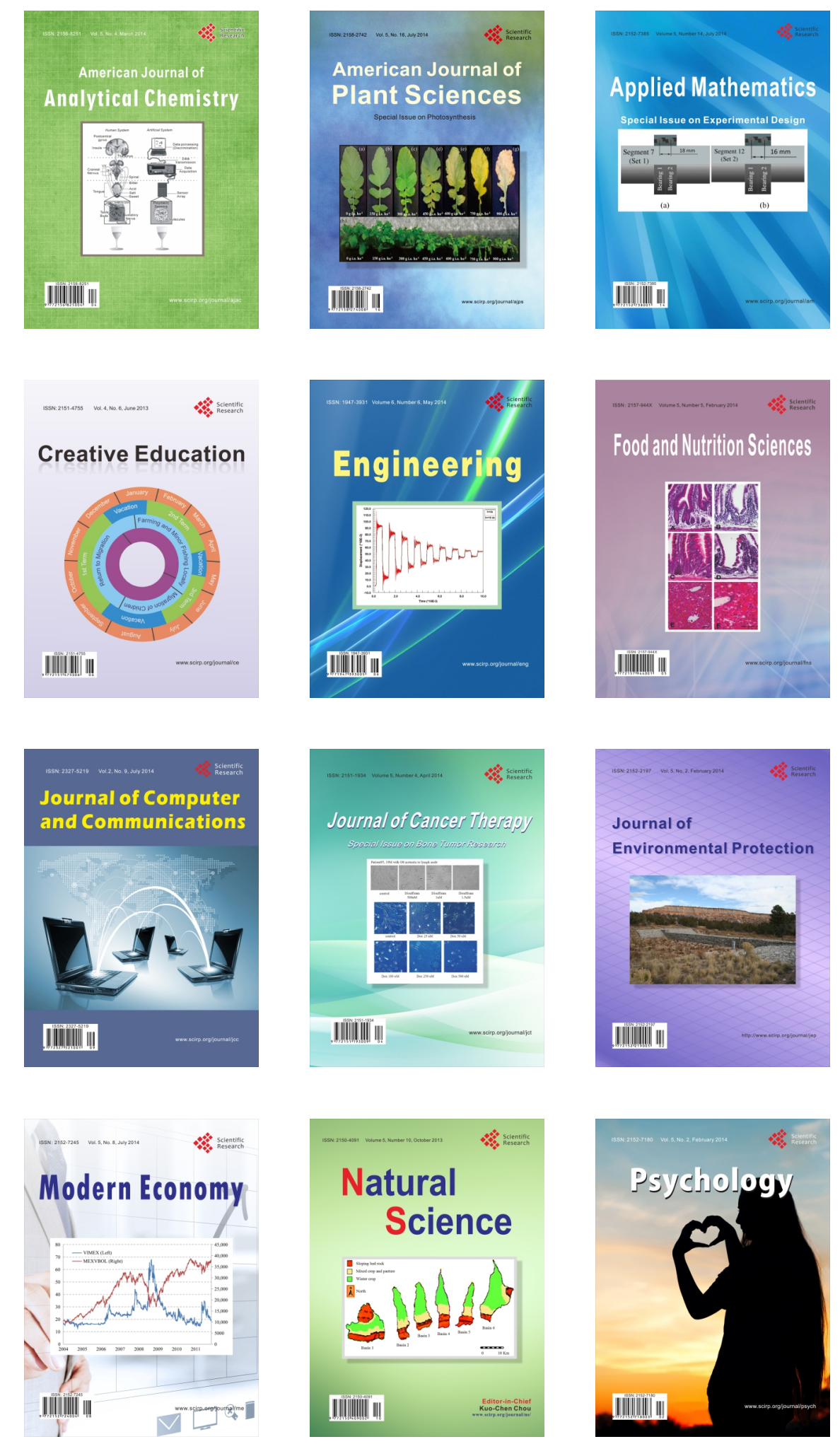